\title{
Barriers Related to Screening Examinations for Prostate Cancer ${ }^{1}$
}

\author{
Elenir Pereira de Paiva ${ }^{2}$ \\ Maria Catarina Salvador da Motta ${ }^{3}$ \\ Rosane Harter Griep ${ }^{4}$
}

\begin{abstract}
With the aim of describing barriers to screening for prostate cancer, a domicile survey was carried out covering 160 men of a Family Health Strategy (FHS) area. Slightly over half had undergone the examination. Regarding beliefs related to the disease, $95 \%$ of the men believed there is a cure if detected early, $29.4 \%$ mentioned the possibility of a normal life while ill, $56.3 \%$ believed it may be asymptomatic, $36.1 \%$ agreed/disagreed that the treatment is worse than the disease and $34.4 \%$ agreed that the examination affects masculinity and that if you are well it is not necessary to perform it. Regarding barriers, $15 \%$ reported that the physician had never requested it, $10.9 \%$ did not consider it important and $16.9 \%$ were afraid to take the examination. While not the sole determinant, the dissemination of adequate knowledge regarding the examination can constitute a key strategy for the formation of a positive attitude in relation to early detection.
\end{abstract}

Descriptors: Religion; Prostatic Neoplasms; Men's Health.

\footnotetext{
1 Paper extracted from Doctoral Dissertation "Conhecimentos, atitudes e práticas acerca da detecção precoce do câncer de próstata" presented to Programa de Pós Graduação, Escola de Enfermagem Anna Nery, Universidade Federal do Rio de Janeiro, RJ, Brazil.

${ }^{2}$ RN, Ph.D. in Nursing, Secretaria Municipal de Saúde de Juiz de Fora, MG, Brazil. E-mail: elenirbolpato@yahoo.com.br.

${ }^{3}$ RN, Ph.D. in Nursing, Adjunct Professor, Escola de Enfermagem Anna Nery, Universidade Federal do Rio de Janeiro, RJ, Brazil. E-mail: macatarina@gmail.com.

${ }^{4}$ RN, Ph.D. in Public Health, Researcher, Laboratório de Educação em Ambiente e Saúde, Fundação Oswaldo Cruz, RJ, Brazil. E-mail: rohgriep@gmail.com.
}

Corresponding Author:

Elenirr Pereira de Paiva

Universidade Federal de Juiz de Fora

Rua Severino Meireles, 23

Bairro Passos

CEP: 30040-025 Juiz de Fora, MG, Brasil

E-mail: elenirbolpato@yahoo.com.br 


\section{Barreiras em relação aos exames de rastreamento do câncer de próstata}

Com o objetivo de descrever barreiras sobre rastreamento do câncer de próstata, realizou-se inquérito domiciliar, abrangendo 160 homens, de uma área da Estratégia de Saúde da Família (ESF). Pouco mais da metade já havia realizado o exame. Em relação às crenças sobre a doença, 95\% deles acreditam na cura se detectado precocemente, $29,4 \%$ referiram possibilidade de vida normal embora doente, 56,3\% acreditam que pode ser assintomático, 36,1\% concordam/discordam que o tratamento é pior que a doença e $34,4 \%$ concordam que o exame afeta a masculinidade e, se estiver bem, não é necessário fazê-lo. Quanto às barreiras, $15 \%$ informaram que o médico nunca solicitou, $10,9 \%$ não acham importante e 16,9\% têm medo de fazer o exame. Embora não seja o único determinante, disseminar conhecimentos adequados sobre o exame pode se constituir em estratégia fundamental para a formação de atitude positiva em relação à detecção precoce.

Descritores: Religião; Neoplasias da Próstata; Saúde do Homem.

\section{Barreras en relación a los exámenes de rastreo del cáncer de próstata}

Con el objetivo de describir barreras sobre rastreo del cáncer de próstata, se realizó una encuesta domiciliar abarcando 160 hombres de una área de la Estrategia de Salud de la Familia (ESF). Poco más de la mitad ya había realizado el examen. En relación a las creencias sobre la enfermedad, 95\% de ellos creen en la cura si es detectado precozmente, $29,4 \%$ refirieron la posibilidad de vida normal a pesar de estar enfermo, $56,3 \%$ creen que puede ser asintomático, 36,1\% está de acuerdo/no está de acuerdo que el tratamiento es peor que la enfermedad y $34,4 \%$ está de acuerdo que el examen afecta la masculinidad y si estuviese bien no sería necesario hacerlo. En cuanto a las barreras, $15 \%$ informaron que el médico nunca lo solicitó, 10,9\% no lo encuentran importante y $16,9 \%$ tiene miedo de hacer el examen. A pesar de que no es el único determinante, diseminar los conocimientos adecuados sobre el examen puede constituirse en una estrategia fundamental para la formación de una actitud positiva en relación a la detección precoz.

Descriptores: Religión; Neoplasias de la Próstata; Salud del Hombre.

\section{Introduction}

In Brazil, prostate cancer is the second most common cancer among men. In absolute values it is the sixth most common type in the world and the type more prevalent in men, representing around $10 \%$ of total cancers. The incidence rate for this cancer in Brazil is about 6 times higher than in developed countries(1). Approximately 52,350 new cases are estimated for 2010(1).

Various factors have been suggested as determinants for the increase in rates of prostate cancer, among them are: the higher life expectancy of the male population; increased knowledge of lay people regarding prostate diseases and their constant identification campaigns, which have revealed more patients with the disease, together with diet and environmental influences, such as high energy consumption, intake of red meat, fats and milk $^{(2)}$.

In recent years, technology has revolutionized our understanding of early diagnosis, treatment and care of prostate cancer. However, the rates of mortality from the disease in Brazil are increasing(1). There are still no definitive answers for this neoplasia, even for 
doubts that remain regarding its causes and the best approach to early detection and its treatment ${ }^{(1-2)}$. These and other questions will be answered through research in this area being developed and through more specific biomarkers being identified to support appropriate care protocols for this pathology(2). Meanwhile, the known measures of early detection indicated should be encouraged(2). Prominent among these are screening for asymptomatic men through the realization of the digital rectal examination (DRE) and through measurement of the level of the prostate specific antigen (PSA). The best way to diagnose prostate cancer is a combination of these two examinations, since exclusive use of the first fails in $30 \%$ to $40 \%$ of diagnoses, the exclusive use of the second fails in $20 \%$ and the association misses only $5 \%$ of $\operatorname{cases}^{(2)}$. Taking all these factors into account, the Ministry of Health developed the National Policy for Prevention and Control of Prostate Cancer, the main objective of which is to reduce the incidence and mortality from prostate cancer in Brazil. The program proposes the development of continuous actions that lead to public awareness of risk factors for cancer, promote early detection of these factors subject to screening, and favor access to quality, equitable treatment throughout the country(3).

For detection to occur effectively, one of the biggest challenges still concerns the inequality of access, often reflected by the social vulnerability of the population(3). It is perceived that access to the health system does not occur evenly across the different regions of the country or even across the different segments of the population $^{(4)}$. Some studies(5-6) have demonstrated that women use the health services more regularly than men and that women seek the services for reasons linked to routine and preventive examinations and men mainly due to illness. Culturally, the male identity is related to the devaluation of self-care and to the low concern with health ${ }^{(6)}$. It is known that men prefer health services that meet their demands more objectively, such as pharmacies and emergency departments which guarantee faster service and resolve their needs with greater ease ${ }^{(5)}$. Moreover, the lack of bond and welcome by the health units may lead to the withdrawal of men from healthcare(7), in addition to factors such as inadequate opening times which are not guided toward the context of the worker(5). It is important to consider that until recently there was no offer of specific male health services in the primary healthcare service.
With regard specifically to the implementation of the digital rectal examination, besides the factors mentioned, the symbolic aspects related to its invasive nature, from the physical and emotional viewpoint, and the dissemination of the fear of undergoing the examination between men themselves are prominent. Additionally, other aspects of a structural nature cannot be ignored, such as access to the examination in the health services and the recommendation of the health professionals, which also directly or indirectly compromise the performance of the detection of this cancer $^{(8)}$.

Recognizing the importance of injuries to male health in the context of public health, the Ministry of Health launched the National Policy for Integral Attention to the Health of the Man seeking to promote health actions that contribute to the comprehension of the reality of male health in its various socio-cultural and politicaleconomic contexts and that, respecting the different levels of development and organization of local health systems, make possible the increase in life expectancy and reduce rates of morbidity and mortality from preventable and avoidable causes in this population ${ }^{(9)}$. Therefore, interventions at the level of public health are necessary. These should be able to reach and sensitize men in relation to prostate cancer, disseminating knowledge necessary to stimulate positive screening practices, especially among higher risk groups. In this sense, the actions of health, as well as the evaluation of their effectiveness are necessary. Although there are actions to stimulate adherence to screening promoted annually in some health units, no studies were found that evaluate the scope, effectiveness and assimilation of the disseminated knowledge. Therefore, this investigation may be useful in this evaluation and could support assertive approaches in the planning of future actions or in the development of campaigns. Understanding the factors involved in the behavior, beliefs, culture and taboos of the men facing the screening, proposed and recommended as the best approach for early detection, may favor strategies aimed at more appropriate prevention practices ${ }^{(9)}$. Considering these aspects, this study aims to describe the barriers to screening for prostate cancer, of an area ascribed to the Family Health Strategy for the municipality of Juiz de Fora - MG.

\section{Methods}

A cross-sectional study, developed through a domicile survey, was conducted, where the study 
population was comprised of a simple random sample of 160 men, aged between 50 and 80 years of age, from a total of 457 male residents of an area ascribed to the Family Health Strategy in the municipality of Juiz de Fora - MG. The sample size calculation was performed using the following formula: $n=N z^{2} p(1-p) /\left[d^{2}(N-1)+z^{2} p\right.$ $(1-p)]$. Where $N=$ total population of men in the age group considered, in the ascribed area (457), $z=$ value corresponding to the confidence level squared $\left(1.96^{2}=\right.$ $3.84), d=$ absolute precision squared $\left(0.06^{2}=0.0036\right)$; $\mathrm{p}=$ proportion of the population with the characteristic under study (0.5).

The adopted inclusion criteria were: males, resident in the community, between 50 and 80 years of age, regardless of the existence of a prior history of prostate cancer. The exclusion criteria covered: males younger than 50 years of age, as they do not constitute priority groups for early detection for this cancer(3), males over 80 years of age, since, among them, urological problems and even cancer are already very frequent, minimizing chances of early detection(2-3).

A questionnaire composed of open and closed questions was used as the research instrument, constructed from questionnaires from other studies ${ }^{(10-12)}$. The translation of the questions from international questionnaires was performed by a Brazilian researcher with a command of the English language. The content validity of the instrument was carried out by a researcher with experience in population studies related to the methods of screening for prostate cancer. After this step three rounds of pre-testing, among men with similar socio-demographic characteristics to the study population, were conducted, allowing the evaluation of the level of understanding of the questions and the improvement of the instrument. The pilot study that tested the logistics of the study was performed with a sample of 30 men from the same community who were not part of the main study. The content of the questions included socioeconomic and demographic variables (age, education, marital status, occupation, income and religion), and beliefs and barriers in conducting screening examinations for prostate cancer. Data analysis was initially carried out by reviewing and manually codifying the forms. Data were then digitalized using Epi-info (2005) and subjected to exploratory statistical techniques: mean, standard deviation (SD) and frequency distributions. This research was approved by the Research Ethics Committee of the Anna Nery School of Nursing of the Federal University of Rio de Janeiro under the Protocol $007 / 07$ on $05 / 02 / 2007$.

\section{Results}

The mean age of the sample was 61.5 years $( \pm 8.0$ years). Regarding race/color, $40.6 \%$ declare themselves white, $20.0 \%$ and $39.4 \%$ black and Mestizo respectively. The vast majority were married. Low levels of education among respondents were identified, with $66.9 \%$ saying they had only incomplete elementary education, $6.3 \%$ complete elementary education, $8.7 \%$ complete high school, $1.2 \%$ reported attending a further education course and $16.8 \%$ reported not having attended school. With regard to household income, the mean wage for the previous month was $\mathrm{R} \$ 308.00$ ( \pm 276.4 reais), while $11.3 \%$ earned up to $1 / 4$ of the minimum wage, $21.3 \%$ receive $1 / 4$ to $1 / 2$ of the minimum wage, $29.4 \%$ receive $1 / 2$ the minimum wage per month, $15 \%$ reported receiving more than one minimum wage and $23.1 \%$ did not declare the family income. Additionally, only $23.1 \%$ had private health insurance and $88.8 \%$ of the male interviewees reported having children (Table 1 ).

Table 1 - Characteristics of the sample $(n=160)$

\begin{tabular}{|c|c|c|}
\hline $\begin{array}{c}\text { Sociodemographic } \\
\text { variables }\end{array}$ & $\mathbf{N}$ & $\%$ \\
\hline \multicolumn{3}{|l|}{ Age } \\
\hline Mean (SD) & $61.5(8.0)$ & Variation: 50 to 80 years \\
\hline 50 to 56 & 54 & 33.8 \\
\hline 57 to 65 & 57 & 35.6 \\
\hline 66 and over & 49 & 30.6 \\
\hline \multicolumn{3}{|l|}{ Race/color } \\
\hline White & 65 & 40.6 \\
\hline Black & 32 & 20.0 \\
\hline Mestizo & 63 & 39.4 \\
\hline \multicolumn{3}{|l|}{ Marital status } \\
\hline Single & 11 & 6.8 \\
\hline Married & 111 & 69.4 \\
\hline Separated & 22 & 13.8 \\
\hline Widowed & 16 & 10.0 \\
\hline \multicolumn{3}{|l|}{ Schooling } \\
\hline Incomplete elementary & 107 & 66.9 \\
\hline Complete elementary & 10 & 6.3 \\
\hline Secondary & 14 & 8.8 \\
\hline Further & 2 & 1.2 \\
\hline Did not attend school & 27 & 16.8 \\
\hline \multicolumn{3}{|l|}{ Household income (in reais) } \\
\hline Mean (SD) & $308.0(276.4)$ & Variation: 0 to 2,100 \\
\hline 0 to 95 (up to $1 / 4 \mathrm{MW}$ ) & 18 & 11.3 \\
\hline 96 to $190(1 / 4$ to $1 / 2 \mathrm{MW})$ & 34 & 21.2 \\
\hline 191 to $380(1 / 2$ to $1 \mathrm{MW})$ & 47 & 29.4 \\
\hline$>380(>1 \mathrm{MW})$ & 24 & 15.0 \\
\hline No information & 37 & 23.1 \\
\hline \multicolumn{3}{|c|}{ Have private health insurance } \\
\hline No & 123 & 76.9 \\
\hline Yes & 37 & 23.1 \\
\hline
\end{tabular}

(continue...) 
Table 1 - (continuation)

\begin{tabular}{lcc}
\hline $\begin{array}{c}\text { Sociodemographic } \\
\text { variables }\end{array}$ & $\mathbf{N}$ & $\%$ \\
\hline Have children & 17 & 10.6 \\
No & 142 & 88.8 \\
Yes & 1 & 0.6 \\
No response & & \\
\hline
\end{tabular}

Table 2 - Practices regarding screening examinations $(n=160)$

\begin{tabular}{lcc}
\hline \multicolumn{1}{l}{ Practices related to the prostate examination } & N & $\%$ \\
\hline Has any physician informed that the prostate & & \\
examination should be performed & 98 & 61.3 \\
Yes & 59 & 36.9 \\
No & 3 & 1.9 \\
Do not know/do not remember & & \\
Previously performed the prostate examination & 87 & 54.4 \\
Yes & 71 & 44.4 \\
No & 2 & 1.3 \\
Do not know/do not remember & & \\
Reason for request & 53 & 61.6 \\
Routine of prevention & 18 & 20.9 \\
Had symptoms & 11 & 12.8 \\
The participant himself requested & 1 & 1.2 \\
Cases of cancer in the family & 4 & 3.4 \\
Other & & \\
When was the last time the examination was performed & 50 & 58.8 \\
Less than one year ago & 18 & 21.2 \\
Between one and two years ago & 11 & 12.9 \\
Between three and five years ago & 8 & 6.9 \\
More than five years ago & & \\
Previously performed PSA & 83 & 51.9 \\
Yes & 72 & 45.0 \\
No & 5 & 3.1 \\
Do not know/do not remember & 55 & 65.5 \\
When was the last time the PSA was performed & 15 & 17.9 \\
Less than one year ago & 5 & 6.0 \\
Between one and two years ago & 5 & 6.0 \\
Metween three and five years ago than five years ago & 3 & 2.4 \\
\hline Do not know/do not remember & & \\
\hline & & \\
\hline
\end{tabular}

Of the screening practices performed by the interviewees, $61.3 \%$ of men reported that a physician had already informed them that they ought to undergo the prostate examination, only $54.4 \%$ had undergone the examination and the main reason was performing was "a routine of prevention", reported by $61.6 \%$ of respondents. However, just over half had undergone the examination within the previous year (58.8\%). Regarding undergoing PSA, $51.9 \%$ said that they had, and $65.5 \%$ reported having performed this examination within the previous year.
Table 3 - Beliefs in relation to prostate cancer $(n=160)$

\begin{tabular}{lccc}
\hline & $\begin{array}{c}\text { Agree } \\
\%\end{array}$ & $\begin{array}{c}\text { Disagree } \\
\%\end{array}$ & $\begin{array}{c}\text { Do not know } \\
\%\end{array}$ \\
\hline $\begin{array}{l}\text { Ca can be cured if detected } \\
\text { early }\end{array}$ & 95.0 & - & 5.0 \\
$\begin{array}{l}\text { A man with Ca can have a } \\
\text { normal life }\end{array}$ & 29.4 & 57.5 & 13.1 \\
$\begin{array}{l}\text { The treatment of Ca is worse } \\
\text { than the disease }\end{array}$ & 36.1 & 36.1 & 27.8 \\
$\begin{array}{l}\text { A man can have Ca without } \\
\text { symptoms }\end{array}$ & 56.3 & 25.0 & 18.7 \\
$\begin{array}{l}\text { If you have Ca it is better to } \\
\text { keep it quiet and not treat it }\end{array}$ & 20.0 & 74.4 & 5.6 \\
$\begin{array}{l}\text { The prostate examination can } \\
\text { affect masculinity }\end{array}$ & 34.4 & 53.1 & 12.5 \\
$\begin{array}{l}\text { If you are well it is not necessary } \\
\text { to do the examination }\end{array}$ & 34.4 & 65.0 & 0.6 \\
\hline
\end{tabular}

With reference to the beliefs that involve the detection and treatment of prostate cancer presented in Table 3, it was found that $95 \%$ of the men agreed that prostate cancer can be cured if detected early and $57.5 \%$ disagreed that a man with prostate cancer may have a normal life. Similar proportions of interviewees (36.1\%) agreed and disagreed with the statement that the treatment is worse than the disease. Among them, $56.3 \%$ agree that a man may have prostate cancer and not show symptoms, and $74.4 \%$ disagreed with the statement that it is better not to treat it. Another salient aspect is that although the majority (53.1\%) disagreed with the statement the prostate examination affects masculinity, about a third of them agreed and two thirds of the men disagreed with the statement that if the man is well, is not necessary to undergo the examination.

Based on Table 3, the lack of knowledge of the interviewees regarding statements related to the treatment and the prostate cancer itself is highlighted, for example, $27.8 \%$ responded "do not know" to the statement "Cancer treatment is worse than the disease" and $18.8 \%$, to the statement "A man may have prostate cancer without symptoms".

Table 4 - Barriers in relation to screening $(n=71)$

\begin{tabular}{lcc}
\hline \multicolumn{1}{c}{$\begin{array}{c}\text { Barriers mentioned for undergoing } \\
\text { the examination }\end{array}$} & N & $\%$ \\
\hline The physician has never requested & 24 & 33.8 \\
Afraid of doing it & 12 & 16.9 \\
Prefer not to know of a disease such as prostate & 11 & 15.0 \\
cancer & 11 & 15.0 \\
Have never shown symptoms & 8 & 10.9 \\
Have never considered it important & 2 & 2.8 \\
Do not have time & 2 & 2.8 \\
Thought men did not have to do it & 1 & 1.4 \\
Unable to make an appointment with a specialist & 1 & 1.4 \\
Do not know & & \\
\hline
\end{tabular}


The main reason given by interviewees who had not undergone the screening examinations for prostate cancer was that the doctor had never requested it. A considerable proportion reported that they "were afraid to do it", followed by "I prefer not to know that I have cancer", "I have never shown symptoms" and "I have never considered it important" (Table 4).

\section{Discussion}

Low socioeconomic status was identified in the sample, characteristic of many areas ascribed to the Family Health Strategy in the municipalities. The unfavorable socioeconomic conditions provide less access to the health system and consequently a greater exposure to health problems, with cancer possibly being one of these(10). Screening examinations for prostate cancer are certainly the most important step in its treatment, especially in developing countries, because it is in this initial phase of the disease where the opportunity exists to offer men a cheap and effective method of treatment, contributing to the maintenance of the quality of life $\mathrm{e}^{(2)}$. Thus, it is not possible to separate the role of those responsible for adopting public policies and the professionals of the area, in the aspect of health education of the population. Complementing the socioeconomic profile of the sample, the analysis of the educational situation shows nothing favorable. Some authors ${ }^{(10-11)}$ associate lack of information on the prevention or treatment of prostate cancer with low levels of schooling. This indicates that misinformation more severely affects the male population with lower educational levels and less socio-economic power, which requires educational actions aimed mainly at this group.

Slightly more than half of the men reported having performed screening examinations for prostate cancer, identifying an inadequate frequency of performance in the previous twelve months. These results reflect the inadequate screening coverage among the population, since the recommendation is that they are performed annually ${ }^{(2-3)}$, therefore the data reflect missed opportunities for prevention. These data indicate the need for responsibility and commitment for the planning of health actions, because the early detection examinations are essential for prostate cancer. In relation to the beliefs reported by the men of the study, it was found that the vast majority believe that cancer can be cured if diagnosed early. In a study where the subjects had a similar socio-demographic profile to the sample ${ }^{(11)}$ similar results were found, with the authors reporting that the majority of subjects believed that cancer can be detected by the screening examinations. However, a percentage considered the treatment to be worse than the disease (36.1\%) due to ignorance about this. The heavy impact caused by prostate cancer makes men create barriers for this treatment due to factors such as: lack of information; preconceptions regarding the digital rectal examination and fear of seeking the urologist and undergoing this type of examination; the difficulty of access to medical specialists; and fear of becoming impotent ${ }^{(12)}$.

About a third of male interviewees considered that the prostate examination affects masculinity. The subjective issue of masculinity, while little discussed, can be seen as "the possibility of admitting weakness or disability, or feeling that the illness could reduce their productive capacity, could jeopardize the invulnerability accorded to the man and therefore his masculinity"(12-13). It is known that at the moment of the prostate examination, more precisely the digital rectal examination, the man is placed in an embarrassing situation, therefore health professionals should consider the subjective aspects that involve the rectal examination in their discussions. Along these lines of thought, there are authors ${ }^{(5,8,14)}$ that deepen the discussion on the digital rectal examination, considering also the pain and fear, as this examination can lead to a man being touched in his "lower" regions and that the examination involves penetration and may be associated with pain and also with violation. In this sense, it is necessary to observe these issues when planning screening activities.

Some of the interviewees reported fear as a barrier to undergoing the examination. This fact is not uncommon among men, while some authors ${ }^{(8,12,14)}$ consider that "even if the man does not feel pain, they, at least, experience the physical and psychological discomfort of being touched, in a prohibited area". This barrier has also been expressed by participants in international studies ${ }^{(14-15)}$ as "a lack of courage (fear)" and as others such as the absence of symptoms, the physician does not recommend, the physician did not relate the causes. These results show that both Latin and the North American men have similar taboos in relation to early detection examinations. The act of undergoing the digital rectal examination is delicate for the man, because at this moment, his view of masculinity may be threatened(6).

In general, studies concerning the prevention of prostate cancer focus on aspects related to the 
clinical part of the examinations involved, not taking into account the subjective aspects, mainly related to masculinity ${ }^{(5,7-8)}$. Usually the man possesses a macho imaginary, which brings the idea that his body was not meant to be penetrated, but to penetrate. The approach to the sexual aspects leads to the question of the cultural force in people's patterns of behavior. The rectal examination may refer to the issue of homosexuality, behavior considered deviant in society, especially by the church, which emphasizes procreation as the primary purpose of sexual life. Thus, men are taught to pursue heterosexuality and repel any attitude that is closer to homosexuality ${ }^{(6,8)}$.

Regarding the various barriers identified, the absence of the physician's request is emphasized. This represents a lost prevention opportunity for public health, because the proposal from the FHT aims to emphasize a new concept of healthcare, through actions of prevention and intervention related to the risk factors and through the development and promotion of quality of life. Priority actions are proposed which are performed with emphasis on educational activities, prevention of risks and specific injuries, and also on basic actions of healthcare for priority groups in a given territory ${ }^{(15)}$. Furthermore, this result could be linked to the fact that many men do not feel they have the right to request a preventive examination during the medical consultation. Therefore, opportunities to detect a disease, where prevention is essential, could be being lost in the health service, since the men who go there leave without the examination being requested.

The fact that some men do not think it important to undergo the examination may reflect a total ignorance about the disease, and lack of access of this group to local health actions. Given this fact educational measures must be priorities for this specific group, because one of the biggest challenges in healthcare is still related to the inequality of access, often reflected by the social inequality of the population ${ }^{(4,7)}$.

Not having time was also an issue highlighted by the men. This aspect is crucial for the planning of health actions, as it is known that the basic health units often work during the day coinciding with the work period of many men, therefore this group has to be included in the daily schedule of the units. Analyzing the healthcare in the Primary Healthcare Units ${ }^{(5)}$ it can be seen that the developed work takes place with the focus placed on women, children and the elderly, where the healthcare of men takes place indirectly, when they are included in preventive care groups such as hypertension or diabetes. Emergency care constitutes the predominant form of access to health services for men. However, this form of care can provide the men with the feeling they do not belong in the preventative healthcare space, and cause them to withdraw further from searching for prevention in health. Some men of the sample reported that they prefer not to know of a disease like cancer. This statement shows that the fear of this disease is present in the evaluated population and that this aspect and the possibilities of treatment and cures available today are important considerations.

The fear of the rectal examination, which involves penetration, can be associated with both physical and symbolic pain, and also with violation. Another factor considered is the fear of erection during the examination that could be seen as pleasure. In the masculine imaginary, "the erection may be associated with pleasure and cannot be imagined as physiological"(6). In this sense, the health actions in the Primary Healthcare Units should involve both the primary preventive strategies, encompassing the risk factors or predispositions and also those of a secondary character, which include early diagnosis and the appropriate therapeutic approach to prevent disability and mortality that may result from the disease ${ }^{(5,7,15)}$.

The absence of symptoms related to prostate cancer is a barrier that can be taken as an indicator of lack of development of preventive actions in these men because they think that, to undergo the exam, you must be ill. It is common among the populations of developing countries to understand that there is no need to go to the physician when you do not feel anything ${ }^{(14,16-18)}$.

\section{Final Considerations}

The prevention and early detection, basic strategies for the control of prostate cancer, have as an essential prerequisite a combination of constant, persistent and dynamic educational activities for men, according to their standards of values and education, among other variables. It is believed that such educational activities should prioritize the urgent need for change in behavior both by men and by the services in prioritizing screening examinations.

Here the incorporation of the community in healthcare is highlighted, through the planning of actions, linked with organized sectors of the community and other governmental sectors. While acknowledging that this is not the sole determinant, to disseminate relevant knowledge about the examination can serve as 
a key strategy for the formation of a positive attitude in relation to early detection.

Finally, these findings present an opportunity for debate on the subject, offering support for rethinking the training of the nurse and their practice in the health of the man, while pointing out the need to conduct further research in the area.

\section{References}

1. Ministério da Saúde (BR). Secretaria de Atenção a Saúde: Departamento de Ações Programáticas Estratégicas. Política Nacional de Atenção Integral à Saúde do Homem (Princípios e Diretrizes). Brasília (DF); agosto 2008.

2. Srougi M. Próstata: isso é com você. São Paulo: Publifolha; 2003.

3. Ministério da Saúde (BR). Instituto Nacional de Câncer. Secretaria de Atenção à Saúde. Instituto Nacional de Câncer. Coordenação de Prevenção e Vigilância de Câncer. Estimativas 2008: Incidência de Câncer no Brasil. Rio de Janeiro: INCA; 2007.

4. Lima AJC, Azory EB, Bastos LHC, Coutinho MM, Pereira NN, Ferreira SCC. Desigualdades no acesso e utilização de serviços de saúde no Brasil. Saúde Debate. 2002; 26(2):62-70.

5. Figueiredo W. Assistência à saúde dos homens: um desafio para os serviços de atenção primária . Ciênc Saúde Colet. 2006; 10(1):105-9.

6. Araújo MAL, Leitão GCM. Acesso à consulta a portadores de doenças sexualmente transmissíveis: experiências de homens em uma unidade de saúde de Fortaleza, Ceará, Brasil. Cad Saúde Pública. março-abril 2005; 21(2):396-403.

7. Schimith MD, Lima MADS. Acolhimento e vínculo em uma equipe do programa saúde da família. Cad Saúde Pública. novembro-dezembro 2004; 20(6):1487-94.

8. Gomes R, Nascimento EF, Rebello LEFS, Araújo FC. As arranhaduras da masculinidade: uma discussão sobre o toque retal como medida de prevenção do câncer prostático. Rev Ciênc Saúde Colet. (RJ) 2008; 13(6):1975-84.

9. Ministério da Saúde (BR). Política Nacional de Saúde do Homem. Página na internet 2009 [citado em 2009 ago 27]: [cerca de 8 p.] [acesso 2010 ago 17]. Disponível em: http:// www.portalsaude.gov.br- saude do homem. 10. Hegarty V, Burchett BM, Gold DT, Cohen HJ. Racial differences in use of cancer prevention services among older americans. J Am Geriatr Soc. 2000; 48(5):735-40.
11.Wahnefried, WD, Robertson CN, Walther PJ, Polascik TJ, Paulson DF, Vollmer RT. Pilot study to explore effects of low-fat, flaxseed-supplemented diet on proliferation of benign prostatic epithelium and prostate-specific of benign prostatic epithelium and prostate-especific antigen. J. Adult Urol. 2004;63(5):900-4.

12. Burack RC \& Wood DP Jr. Screening for prostate cancer. The challenge of promoting the informed decision making in the absence of definitive evidence of effectiveness. Med Clin North Am 1999;13(83):142342.

13. Lara M. Com todas as letras. O estigma do câncer por quem enfrentou esse inimigo silencioso e cruel. Rio de Janeiro: Record; 2005.

14. Lucumí-Cuesta DI, Cabrera- Arana GA. Creencias de hombres de Cali. Colômbia sobre el examen digital rectal: hallazgos de um estúdio exploratório. Cad Saúde Pública. 2005; 21(5):1491-8.

15. Czresnia D, Freitas CM. Promoção da saúde: conceitos, reflexões, tendências. Rio de Janeiro: Fiocruz; 2003.

16. Gomes R, Rebello L, Araujo F, Nascimento EF. A prevenção do câncer de próstata. Ciênc Saúde Colet. 2008; 12(1):235-46.

17. Arroll B, Pandit S, Buetow S. Prostate câncer screening: Knowledge, experiences and attitudes of men aged 40-79 years. NZ Med J. June 2003, 116(1176):1-8.

18. Cormier L, Kwan L, Reid K, Litwin MS. Knowledge and beliefs among brothers and sons of men with prostate cancer. Rev Adult Urol. 2002; 59(6):895-900.

Received: Nov. $18^{\text {th }} 2009$

Accepted: Nov. 22 2010 